\title{
Isolation, Identification and Antimicrobial Susceptibility Test of Mastitis Causing Bacteria at Holeta Agricultural Research Center Dairy Farms
}

\author{
Kanenus Dereje ${ }^{1}$, Abriham Kebede ${ }^{2, *}$, Nigus Abebe ${ }^{3}$, Yobsan Tamiru ${ }^{2}$ \\ ${ }^{1}$ Wama Hagalo Districts of East Wollega Zone, Oromia Region, Nekemte, Ethiopia \\ ${ }^{2}$ School of Veterinary Medicine, College of Medical and Health Science, Wollega University, Nekemte, Ethiopia \\ ${ }^{3}$ College of Veterinary Medicine, Mekelle University, Mekelle, Ethiopia \\ Email address: \\ abrahamkebede2016@gmail.com (A. Kebede), kanenus dereje@gmail.com (K. Dereje), nigus abebe@gmail.com (N. Abebe), \\ yobsanraji@gmail.com (Y. Tamiru) \\ ${ }^{*}$ Corresponding author
}

\section{To cite this article:}

Kanenus Dereje, Abriham Kebede, Nigus Abebe, Yobsan Tamiru. Isolation, Identification and Antimicrobial Susceptibility Test of Mastitis Causing Bacteria at Holeta Agricultural Research Center Dairy Farms. International Journal of Animal Science and Technology.

Vol. 2, No. 1, 2018, pp. 6-13. doi: 10.11648/j.ijast.20180201.12

Received: November 17, 2017; Accepted: November 29, 2017; Published: January 17, 2018

\begin{abstract}
A cross-sectional study was conducted from November 2014 to April 2015 to determine the prevalence of bovine mastitis, isolation of mastitis causing bacteria's and characterize antimicrobial susceptibility pattern at Holeta Agricultural Research Centre (HARC) Dairy Farms. Purposive sampling technique was employed and all lactating cows were involved in the study. Among 186 lactating cows consists of 92 Jersey as well as 94 cross breed (Boran X Holistein Fresian) were included in the study. Among selected cows, $131(70.43 \%)$ cows were identified as bovine mastitis positive and out of which 10 (5.37\%) had clinical mastitis and $121(65.05 \%)$ had subclinical mastitis. The different types of bacterial species isolated in present study includes S. aureus (30.93\%), staphylococcus other than S. aureus (14.43\%), Str. agalactiae (5.15\%), Str. Dysgalactiae (5.15\%), Str. Uberis (12.37\%), C. bovis (13.40\%), E. coli (6.18\%), P. aerogenosa $(10.3 \%)$ and K. pneumonie (2.05\%). Antimicrobial susceptibility testing revealed that $94 \%$ and $78.6 \%$ of total isolates were susceptible to gentamycin and trimethoprim-sulfamethoxazole, respectively which was followed by erythromycin and tetracycline with susceptibility rate of $73.8 \%$ and $69 \%$, respectively. However, penicillin had shown susceptibility of $55.9 \%$ which was the least effective among the drugs used. In conclusion, different types of mastitis causing pathogens with variable rate of susceptibility to antimicrobials were able to identify. Therefore, antimicrobial therapy should be used after isolation of the suspected pathogen to avoid emergence of drug resistance.
\end{abstract}

Keywords: Antimicrobial, Dairy, Isolation, Mastitis, Susceptibility, HARC

\section{Introduction}

In Ethiopia, livestock represents a major national resource and form an integral part of the agricultural production system. The total cattle population for the country is estimated to be about 55.03 million, out of which about 55.38 percent are females (CSA, 2014).

Milk produced from these animals provides an important dietary source for the majority of rural as well as considerable number of the urban and per urban population. However, milk production often does not satisfy the countries requirement. According to the reports of FAO, the total annual national milk production in Ethiopia ranges from 797, 9000 to $1,197,500$ metric tons raw milk. Out of the total national milk production, between 85 and 89 percent is contributed from cattle. Nevertheless, this amount is by far below the national demand for milk and milk products in the country, given the considerable potential for smallholder income and employment generation from high value dairy products (FAO, 2009).

Development of the dairy sector in Ethiopia can contribute significantly to poverty alleviation and nutrition in the country (Mohamed et al., 2004). On the other hand the 
quality and quantity of milk in the country deteriorates due to various causes, out of which disease of the mammary glands known as mastitis is among the various factors contributing to reduced milk production (Fekadu, 1995).

Mastitis is inflammation of the parenchyma of the mammary gland regardless of the cause. It is characterized by a range of physical and chemical changes in the milk and pathological changes in the glandular tissue (Radostits et al., 2007).

Mastitis is a complex and multi factorial disease, the occurrence of which depends on variables related to the animal, environment and pathogen (Radostits et al., 2007). Among the pathogens, bacterial agent are the most common one, the greatest share of which resides widely distributed in the environment of dairy cows, hence a common threat to the mammary gland (Bradley, 2002).

Mastitis induced via pathogenic microorganisms that generally come from two sources, either environmental exposure of teat to contaminated environment, or the animal itself. Staphylococcus aureus and Streptococcus agalactiae which are predominant pathogens to cause bovine mastitis) that comprises contagious bacteria causing mastitis (Erskine, 2001; Radostits et al., 2007).

Normally, the teat canal is tightly closed by sphincter muscles, preventing the entry of pathogens. It is lined with keratin, a waxy material derived from stratified squamous epithelium that obstructs the migration of bacteria and contains antimicrobial agents, such as long-chain fatty acids, that assist in combating the infection. However, the efficiency of keratin is restricted (Paulrud, 2005). Fluid accumulates within the mammary gland as parturition approaches, resulting in increased intra mammary pressure (Paulrud, 2005) and mammary gland vulnerability caused by the dilation of the teat canal and leakage of mammary secretions. Additionally, during milking, the keratin is flushed out and there is distension of the teat canal (Riollet and, Rainard 2006).

Mastitis can be classified as clinical or subclinical depending on the presence or absence of clear clinical signs. Clinical cases of mastitis are illustrated by the presence of one or more of symptoms such as abnormal milk, udder swelling and systemic signs including elevated temperature, lethargy and anorexia (Eriskine, 2001). Mild clinical mastitis causes flakes or clots in the milk, whereas severe cases are associated with hot, swelling and discolouration of the udder, as well as abnormal secretion. Severe clinical mastitis can also exhibit systemic reactions, such as fever and loss of appetite. The duration of infection further classifies mastitis as acute or chronic manifestations, where a sudden onset defines acute cases and chronic mastitis is characterized by an inflammatory process that lasts for months and results in progressive development of fibrous tissue (IDF, 1987).

Mastitis can exist in the absence of visible signs of infection, and is then referred to as subclinical mastitis. It is the most prevalent form of mastitis (Akers, 2002). Sub clinical mastitis are those in which no visible appearance of changes in the milk or udder, but milk production decreases, bacteria are present in the secretion and composition is altered. For every case of clinical mastitis there are 20-40 times as many cases of sub clinical mastitis (Eriskine, 2001).

The current standard method of detecting subclinical mastitis is to measure somatic cell count (SCC). Other inflammatory parameters, such as electrical conductivity, lactose, lactate dehydrogenase, acute phase proteins, etc, have been proposed as indicators of subclinical mastitis, and some have the potential of being adapted to in-line use (Hamann, 2005).

Mild cases of clinical mastitis (abnormal secretion only) may not require treatment; however, all clinical mastitis episodes accompanied by an abnormal gland or systemic signs of illness should be treated with antimicrobial agents given by intra mammary infusion (all cases) and parenterally (selected cases). Acute and peracute mastitis cases require also supportive therapy (fluid and electrolytes) and nonsteroidal anti-inflammatory a gents NSAIDs (Radostits, et al., 2007).

Mastitis imposes a serious problem cause reduction in milk production (Korhonen and Kaartinen, 1995) and remains one of the most economically important diseases for the dairy industry worldwide irrespective of the species of animals (Bradley, 2002). Moreover, mastitis can cause devastating effects to farmers because of the serious economic losses and the danger that the bacterial contamination of milk from affected cows may render it unsuitable for human consumption (Quinn et al., 2002). Furthermore, mastitis occurs worldwide among dairy animals and it has been described to have zoonotic impact (Al-Majali et al., 2008).

As described by Hogeveen (2011), Worldwide, published estimates of the economic losses of clinical mastitis range from $€ 61$ to $€ 97$ per cow on a farm, with large differences between farms, e.g. in The Netherlands, losses due to clinical and subclinical mastitis varied between $€ 17$ and $€ 198$ per cow per year. In USA mastitis is a significant disease of adult dairy cattle affecting up to 40 percent of cows within a herd at any given time. Recent surveys show that udder health problems are consistently the most frequent cause of morbidity in the country dairy cattle population. The US dairy industry loses an estimated $\$ 2$ billion every year due to mastitis, with reduced milk production accounting for the majority of the total economic loss (Sordilo, 2009).

Although the occurrence of mastitis in Ethiopia has been reported from different parts of the country (Almaw et al., 2009), regular and systematic studies of the disease should be carried out in order to make information on the prevalence of the disease available and put forward an appropriate disease control strategies for this economically important disease. Bovine mastitis is the second most frequent disease next to reproductive disorders and one of the major causes for economy failure in Ethiopia. It affects both the quantity and quality of milk. About 140 to 200 USD /Cow/Yearis lost due to mastitis with approximately $8 \%$ being due to discarded milk, $8 \%$ for treatment cost, $14 \%$ to death and premature culling and $70 \%$ to reduced milk production (Capuco et al., 1992). Therefore the purpose of this study was: 
1. To find out the prevalence of bovine mastitis in Holeta Agricultural Research Center dairy farms.

2. To characterize mastitis causing pathogenic bacteria in the study area.

3. To determined the antimicrobial susceptibility of the isolated mastitis causing pathogens.

\section{Materials and Methods}

\subsection{Study Area}

The study was conducted at Holeta and Adabarga dairy farms owned by Holleta Agricultural Research Center (HARC). Holleta is located in central highland of Oromia special zone surrounding Finfine, Ethiopia at latitude of $38^{\circ}$ $30^{\prime} \mathrm{E}, 9^{\circ} 3^{\prime} \mathrm{N}$ and $29 \mathrm{~km}$ west of Addis Ababa on high way to Ambo. It has an altitude of 2400 meter above sea level. The area receives mean annual rain fall of $1100 \mathrm{~mm}$ with bimodal distribution, $70 \%$ of which occurs during the main rainy season (June to September) and 30\% during the small rainy season (February to April) and annual temperature of 11 to $22^{\circ} \mathrm{C}$ with relative humidity of $50.4 \%$ (Ararsa et al., 2014).

\subsection{Study Animals}

The study animals comprises of crossbred dairy cows (Borana $\times$ Holstein Fresian) and Jersey breed owned by HARC. The animals were often managed under a semiintensive management system. They are often provided with some supplementary diet in addition to the natural pasture and agricultural byproducts and some are maintained usually in separate stalls, a short distance from each other in a house. Pre-milking and post-milking hygienic procedures, such as udder washing and drying, were frequently practiced. Cows were allowed to dry off at late-lactation period by abrupt cessation of milking.

\subsection{Study Design and Sampling Technique}

Cross-sectional study was conducted from November 2014 to April 2015 in lactating dairy cows at Holeta Agricultural research center farms. Two dairy farms namely Holeta and Adabarga dairy farms were purposively selected. All lactating dairy cows during the study period were included in the study.

\subsection{Data Collection}

In the beginning the researcher observed both farms of HARC dairy farms. During this observation data of hygienic practices of the farms, system of manure removal, milking practices of the farm and types farming system was identified.

\subsubsection{Physical Examination}

Characteristics of study animals for example, breed parity, lactation stage, average milk yield and body condition score of the lactating cows were collected by looking the registration book of each dairy farm.

The cardinal signs of inflammation such as hotness, pain, swelling, redness and loss of function of teats and its associated structures were examined through visual inspection and palpation. Furthermore, abnormal changes in the milk including its color and presence/absence of clotting materials were recorded. Where, the above conditions are results of clinical inspection of udder based on Quinn et al, (2002). Hence, based on physical examination, animals were classified as clinically affected by bovine mastitis and apparently healthy.

\subsubsection{Detection of Subclinical Mastitis}

\section{i. Preparing Udders and Teats}

The udders, especially teats were cleaned and dried before sample collection. Each teat end was scrubbed vigorously with a pledged of cotton moistened with $70 \%$ of ethyl alcohol. Recontamination of teats during scrubbing was avoided by scrubbing, and separate pledged cotton was used for each teat.

Subclinical mastitis was detected using the California Mastitis Test (CMT). A squirt of milk, about $2 \mathrm{ml}$ from each quarter was placed in each of four shallow cups in the CMT paddle. An equal amount of the commercial reagent of CMT was added to each cup. A gentle circular motion was applied to the mixtures in a horizontal plane for 15 seconds. Accordingly, Sub clinical mastitis was diagnosed based on CMT results by observing the nature of coagulation and viscosity of the mixture. The interpretation (grades) of the CMT was evocated and the results graded as 0 for negative and trace 1, 2 and 3, for positive (Quinn et al., 2002).

\section{ii. Bacterial Culture and Isolation}

During milk sample collection, the first 2 to 3 streams of milk were discarded. The collecting sample bottle was held as near horizontal as possible, and by turning the teat to a near horizontal position, approximately $3-5 \mathrm{ml}$ of milk was collected into a sample collection bottle. After collection, the samples were placed in icebox and taken to Holleta Agricultural Research Center Animal Biotechnology laboratory for bacterial culture and isolation.

All samples of milk was streaked on blood agar plate and macconkey agar plate which then were incubated aerobically at $37^{\circ} \mathrm{C}$ and observed within 24 to 72 hours for growth of bacteria causing mastitis. In the beginning, identification of the bacteria was performed by identifying the growth either on blood agar only or both macconkey and blood agar plate. Then followed by colony morphology (colony size, shape, color, viscosity), haemolysis (presence or absence of haemolysis, type of haemolysis), staining technique based on gram stain (Gram positive or negative, bacterial shape, structure, arrangement), $\mathrm{KOH}$ test and catalase test according to the standards described by Vandepitte and Verhegen, (2003), and SVLD, (2005) in the following table 1. 
Table 1. Different Selective Media and Biochemical Tests.

\begin{tabular}{lllllllll}
\hline \multirow{2}{*}{ Test } & \multicolumn{2}{l}{ Bacterial types } & & & & & \\
\cline { 2 - 8 } & S. aureus & $\begin{array}{l}\text { Other } \\
\text { sthaphylococcus }\end{array}$ & $\begin{array}{l}\text { Str. } \\
\text { agalactiae }\end{array}$ & Str. dysgalactiae & Str. uberis & E. coli & P. aerogenosa & K. pneumonia \\
\hline Catalase & + & + & - & - & - & - & - & - \\
KOH & - & - & - & - & - & + & + & + \\
Hemolysis & + & + & B & A & - & - & \pm & \pm \\
Manitol & + & + & - & - & - & - & - & - \\
Edward & - & - & + & + & + & - & - & - \\
Asculinhydrolysis & - & - & - & - & - & - & - & - \\
CAMP test & - & - & - & - & - & - & - \\
Citrate utilization & - & - & - & - & - & - & - \\
Grow at 42 & - & - & - & - & - & - & - \\
DNAase & + & - & - & - & - & - & - \\
EMB & - & - & - & - & - & - & - \\
\hline
\end{tabular}

*** $\mathrm{KOH}=$ Potasium oxide, $\mathrm{CAMP}=$ Christie, Atkins, Munch and Peterson, $\mathrm{EMB}=$ eosin methyl blue, DNAase $=$ Deoxyribonuclase, $\mathrm{A} \& \mathrm{~B}=$ types of hemolysis.

Source: (Vandepitte and Verhegen, 2003; SVLD, 2005).

The colonies was sub-cultured on selective media such as Edward's media to identify Streptococcus bacteria, mannitol salt agar for Staphylococcus, Eosin methayle blue for identification of E. coli, citrate agar tests for identification of pseudomonas and kilebsiella. Other biochemical tests used to identify the predominant cause of bovine mastitis were used based on that of Quinn et al, (2002).

\section{iii. Antibiotic Susceptibility Test}

The antimicrobial resistance patterns of the isolates were determined using the agar disc diffusion technique in accordance with the standard of National Mastitis Council (NMC) guide lines. Muller Hinton agar was used as plating medium. The discs were impregnated with the following antibiotic: Tetracycline, Penicillin, Gentamycin,
Erythromycin, and Trimethoprim-Sulfamethoxazole based on their accessibility. Disks were stored under refrigeration $\left(+4^{\circ} \mathrm{C}\right)$ to ensure maintenance of their potency. The well isolated bacteria were dissolved in the saline water $0.9 \%$ until visible turbidity compared to $0.5 \mathrm{Mc}$ far land standard was appeared. Then the plate was inoculated by dissolved bacteria in saline water, antibiotic impregnated disks were applied to the surfaces of the inoculated plates with sterile forceps (NMC, 1999). Zone of inhibition of individual antibiotic agent were interpreted in to susceptible, intermediate, and resistance categories by referring recommended clinical and laboratory standards institute (CLSI, 1997) interpretive standards as indicted in table 2.

Table 2. Zone diameter interpretive standard.

\begin{tabular}{lllll}
\hline Test drug & Disk content & Resistance & intermediate & Susceptible \\
\hline Tetracycline & $30 \mu \mathrm{g}$ & $\leq 11$ & $12-14$ & $\geq 15$ \\
Pencillin & $10 \mu \mathrm{g}$ & $\leq 13$ & $14-16$ & $\geq 17$ \\
Erthyromysin & $15 \mu \mathrm{g}$ & $\leq 13$ & $14-22$ & $\geq 23$ \\
Gentamycin & $10 \mu \mathrm{g}$ & $\leq 12$ & $13-14$ & $\geq 15$ \\
Trimethoprim sulfamethoxazole & $1.25 / 23.75 \mu \mathrm{g}$ & $\leq 12$ & $13-16$ & $\geq 17$ \\
\hline
\end{tabular}

Source: (NCCLS, 1997).

\subsection{Data Analysis}

A data base was developed to store quantitative data from the cross sectional study using Microsoft office Excel 2007 software. STATA version 11 software to compute descriptive statistics of variables collected during the study. The prevalence of clinical and subclinical mastitis was analyzed. Bacterial isolates and antimicrobial susceptibility test were described by frequency and percentage, comparison of bacterial isolates and antimicrobial susceptibilities were performed and the proportion of bacterial resistant to each antibiotic was calculated. Significances of some risk factors such as body condition score; average milk yield and other factor were analyzed by chi square. P-value $<0.05$ was reported as statistically significant.

\section{Results}

\subsection{Prevalence of Mastitis}

A total of 186 Jersey and crossbred lactating cows were examined for prevalence of bovine mastitis. Based on the clinical diagnosis and CMT, $131(70.43 \%)$ cows were found to be affected either with clinical or sub clinical mastitis (table-2). The prevalence of clinical mastitis accounted for 10 $(5.37 \%)$ whereas the sub-clinical mastitis was 121 (65.06\%).

Table 3. Summary of mastitis cases in the study sites.

\begin{tabular}{lll}
\hline Udder health status & Frequency & Percent (\%) \\
\hline Clinical mastitis & 10 & 5.37 \\
Subclinical mastitis & 121 & 65.06 \\
Healthy & 55 & 29.57 \\
\hline
\end{tabular}


All 121 sub clinically infected animals were inspected for four quarters for further detailed analysis. Out of the 484 quarters, 27 (5.58\%) quarters were blind. Rest 457 functional quarters, $265(54.75 \%)$ were affected by Sub-clinical mastitis.

Table 4. Frequency of subclinical mastitis at quarter level.

\begin{tabular}{|c|c|c|c|c|c|c|}
\hline \multirow{2}{*}{ Quarter } & \multirow[t]{2}{*}{ CMT negative quarter (\%) } & \multicolumn{4}{|c|}{ CMT positive quarter (\%) } & \multirow{2}{*}{ Blind teat } \\
\hline & & + & ++ & +++ & Total & \\
\hline $\mathrm{RF}$ & $43(35.54)$ & 17 & 22 & 28 & $67(55.37)$ & $11(9.09)$ \\
\hline RH & $42(34.71)$ & 16 & 24 & 34 & $74(61.16)$ & $5(4.13)$ \\
\hline LF & $57(47.12)$ & 13 & 25 & 20 & $58(47.93)$ & $6(4.95)$ \\
\hline LH & $50(41.33)$ & 14 & 22 & 30 & $66(54.54)$ & $5(4.13)$ \\
\hline
\end{tabular}

\subsection{Bacteriological Result}

Milk samples of 121 at cow level from CMT positive cases were collected and cultured for microbiological examination and 80/121 ( $66.12 \%$ ) were having bacterial colony on blood agar whereas $41 / 121(33.88 \%)$ did not show any growth. Out of 80 positive samples, $16(20 \%)$ of them showed mixed colony of more than one types of bacteria. Samples were not taken from the cows which were positive for clinical mastitis as they were under treatment by animal health professional (veterinarian). Body condition and amount of milk production shows statistically significant effect $(\mathrm{P}<0.05)$ on the occurrence of mastitis of bacterial origin. Poor body condition cows had higher frequency of mastitis than good and medium body condition. Those cows producing more than 4 liters of average milk yield had higher frequency of mastitis. Stages of lactation were not having significant $(\mathrm{P}>0.05)$ effect over occurrence of mastitis (table-5).

Table 5. Summary of body condition score, average milk yield and bacterial culture.

\begin{tabular}{llll}
\hline Variable & $\begin{array}{l}\text { Blood agar culture } \\
\text { result }\end{array}$ & p-value & \\
\hline & Positive & Negative & \\
\hline Body condition score & & & \\
Good & $26(32.50)$ & $13(31.71)$ & \\
Medium & $23(28.75)$ & $12(29.27)$ & 0.0083 \\
Poor & $31(38.75)$ & $16(39.02)$ & \\
$\begin{array}{l}\text { Average milk yield/day } \\
\leq 4 \mathrm{~L}\end{array}$ & $32(40)$ & & \\
$>4 \mathrm{~L}$ & $48(60)$ & $17(41.46)$ & 0.0241 \\
\hline
\end{tabular}

From 80 positive samples collected at cow level, 9 bacterial spp. were isolated. The predominant isolated bacteria were Staphylococcus spp., with isolation rate of 44 $(45.36 \%)$ out of which $S$. aureus were the major pathogens with high frequency of $30 \quad(30.93 \%)$ followed by Staphylococcus other than $S$. aureus having frequency of 14 $(14.43 \%)$. The other dominant bacteria isolated were Streptococcus spp with isolation rate of 22 (22.68\%). From Streptococcus spp., Str. uberis was predominant, whereas the Str. agalactiae and Str. dysgalactiae infection was comparable ratio. The detail relative prevalence of bacterial species from subclinical mastitis was shown in table 6 :

Table 6. Frequency of various bacterial species isolated from subclinical mastitis.

\begin{tabular}{lll}
\hline Spp & Frequency & Percent\% \\
\hline S. aureus & 30 & 30.93 \\
Other sthaphlococcus & 14 & 14.43 \\
Str. agalactiae & 5 & 5.15 \\
Str. dysgalactiae & 5 & 5.15 \\
Str. uberis & 12 & 12.37 \\
c. bovis & 13 & 13.40 \\
E. coli & 6 & 6.18 \\
P. aerogenosa & 10 & 10.3 \\
k. pneumonie & 2 & 2.05 \\
\hline
\end{tabular}

\subsection{Antibiotic Susceptibility Test}

In this study different bacterial species have shown different susceptibility toward five antibiotics discs as summarized in table 7.

Table 7. Summary of antimicrobial susceptibility test.

\begin{tabular}{|c|c|c|c|c|c|c|}
\hline Bacteria & No. of isolated & TTC (\%) & $\mathbf{P}(\%)$ & E (\%) & CN (\%) & SXT (\%) \\
\hline S. aureus & 30 & $25(83.3)$ & $24(90)$ & $26(86.6)$ & $30(100)$ & $25(83.3)$ \\
\hline Other sthaphloccus & 14 & $11(78.5)$ & $9(64)$ & $12(85.7)$ & $11(91)$ & $14(100)$ \\
\hline Str. agalactiae & 5 & $4(80)$ & $4(80)$ & $3(60)$ & $5(100)$ & $4(80)$ \\
\hline Str. dysgalactiae & 5 & $5(100)$ & $3(60)$ & $5(100)$ & $5(100)$ & $4(80)$ \\
\hline S. uberis & 12 & $8(66.6)$ & $8(66.6)$ & $12(100)$ & $10(83.3)$ & $8(66)$ \\
\hline E. coli & 6 & $4(66.6)$ & $0(00)$ & $1(16.6)$ & $6(100)$ & $6(100)$ \\
\hline P. aerogenosa & 10 & $5(50)$ & $2(20)$ & $3(30)$ & $10(100)$ & $4(40)$ \\
\hline Total & 84 & $62(69)$ & $47(55.9)$ & $62(73.8)$ & $79(94)$ & $66(78.6)$ \\
\hline
\end{tabular}

$\mathrm{CN}=$ Gentamycin, $\mathrm{TTC}=$ Tetracycline, $\mathrm{P}=$ Penicillin, $\mathrm{SXT}=$ trimethoprim-sulfamethoxazole, $\mathrm{E}=$ Erthromysin.

Sthaphylococcus aureus were highly sensitive to gentamycin, pencillin and erthromysin. Sthaphylococcus other than s. aureus were highly susceptible to trimethoprim- sulfamethoxazole, gentamycin and erythromycin, where as not as good to pencillin. Streptococcus spp., were highly susceptible to Gentamycin, Erythromycin and tetracycline. E. 
coli, k. pneumonia and paerogenosa were highly susceptible to gentamycin where as resistant to penicillin, and Erythromycin.

\section{Discussion}

The current study showed the prevalence of mastitis in the study area was $70.43 \%$. The current finding is in line with Mekibib et al. (2010) at Holleta area who indicated the cow level overall prevalence of $71.0 \%$. However, it is higher than the reports of Lemma et al. (2001) who indicated that $64.5 \%$ were positive for mastitis at cows' level. Moreover the current result is much higher than reports by Kerro and Tareke (2003) $40 \%$ and $44.1 \%$ by Girma, (2010). On the other hand, the present study is found lower than of the result reported by Dabash et al. (2014) which the overall prevalence of mastitis was $88.9 \%$. The variability in the prevalence of bovine mastitis between reports could be attributed to differences in management of the farms, breeds considered, or technical know-how of the investigators (Radostits et al., 2007).

In this study, the prevalence of clinical mastitis at cow level was in agreement with the report of Husien et al. (1999) and Bishi (1998) who reported 5.7 and 5.3\%, respectively in different parts of Ethiopia. The result was also comparable with report of Tsegai, (1997) (7.14\%) from around Bedele and Enyew, (2004) (3.9\%) from Bahir Dar, Ethiopia. However, the result of the present study was lower than the findings of (Bitew et al., 2010; Bedada and Hiko, 2011 and Demelash et al., 2005), who report $10.3 \%, 10 \%$ and $11.9 \%$, respectively in different parts of the country. This may be due to concurrent disease involvement, interaction of several risk factors relating with animal and virulence of causative organism.

In case of sub clinical mastitis, the prevalence obtained in this study was in agreement with the findings reported by Zerihun et al (2013): who reported $67.8 \%$. However, the prevalence of sub clinical mastitis in present study is higher than previous reports made by Bishi, (1998), Mekibib et al. (2010) and Moges et al. (2011), who studied the prevalence as $34.4 \%, 25.22 \%$ and $30.6 \%$, respectively in different areas of Ethiopia. The difference in the prevalence of bovine mastitis at different time and at different part of the country might be due to treatment protocol of farm management, difference in altitude of study area, having different awareness of mastitis prevention, farm design and farm hygiene.

The result obtained from bacteriological analysis of the sample revealed that $S$. aureus, Staphylococcus other than $S$. aureus, Streptococcus species, C. bovis, P. aeroginosa, E. coli, and $K$. pneumoniewere among the contributors of bacterial pathogen of mastitis in the study sites. The predominant pathogen isolated in this study was $S$. aureus which is in agreement with report of Mulugeta and Wassie, (2013) who reported isolation rate of $30.0 \%$. The predominance and primary role of $S$. aureus isolate in bovine mastitis has also been reported in other studies (Atyaib et al., (2006); Fadlelmoula et al., (2007); Mekbib et al., (2010)). While it was lower than the $39.1 \%$ report of Bedada and Hiko, (2011) and, the $47.1 \%$ reported Makibib et al., (2010). The reason for higher isolation rate of $S$. aureus is the wide ecological distribution inside the mammary gland and skin. In areas where hand milking and improper use of drug is practiced to treat mastitis case, its dominance has been suggested. S. aureus is adapted to survive in the udder and usually establishes mild sub clinical infection of long duration from which it is shed through milk serving as source of infection for other healthy cows and transmitted during the milking process (Radostits et al., 2007). Hence, the organism has been assuming apposition of major importance as a cause of bovine mastitis.

Streptococcus spp. was the second predominant bacterial species isolated. This current report was in agreement with that of Zerihun et al. (2013) who isolated $20.4 \%$. Isolation of streptococcus in this work is comparable with Mulugeta and Wassie, (2013) who reported frequency rate $27 \%$. The isolation of streptococcus species is of interest public health significance as it causes various gastrointestinal upset ranging from abdominal pain to diarrhea (FAO, 1990), and. (Radostits et al., 2007) stated that Streptococcus spp. is the most prevalent along with Staphylococcus spp. However, the lower prevalence as compared to staphylococcus spp. is because Streptococcus agalactiae survives poorly outside the udder, and established infections are eliminated by frequent use of penicillin and other antibiotics.

In this study sthaphlococcus other than s. aureus was third predominant isolate bacteria from all next to streptococcus spp. with frequency rate 14.43 . Result reported from current study was in agreement with report of Workineh et al. (2002) which was $14.9 \%$.

The isolation rate of $E$. coli found in this study was comparable with the findings of Makibib et al. (2010) who reported $4.6 \%$ at Holeta, while it was found lower than the report of Mulugeta and Wosie, (2013) at Wollaita Sodo Southern Ethiopia. From the laboratory result of current study $C$. bovis was also isolated with a relative frequency of $13.04 \%$ which is in agreement with Mulugeta and Wassie, (2013) who reported $12.2 \%$ frequency rate. On the other hand this finding differs from other reports such as Sori et al., (2005); Mekibib et al., (2010); Junaidu et al., (2011). Moreover, the laboratory results indicated that the prevalence of Klebsiella was $2.05 \%$ which is comparable with the result of Biruk and Shemelis, (2015) who reported 3.9\% isolation rate in Addis Ababa. The difference in isolates of this organism and other environmental mastitis causing bacteria may be associated with poor farm hygiene, poor slope of stable areas, poor sanitation keeping of milking material, absence of individual towel usage, absence of intra mammary therapy for dried cows. Especially feces which are common sources of $E$. coli can contaminate the premium directly or indirectly through bedding, calving stalls, udder wash water and milker's hands (Radostits et al., 2007).

The current study antimicrobial sensitivity test revealed that Gentamycin was the first line effective antibiotic. The finding of present study is in agreement with the report of (Birhanu et al., 2013) who reported Gentamaycine was the most effective antibiotics of the total isolates found to be susceptible. Because these drugs were the least frequently 
used in the study area in Veterinary service, the drug resistivity had not been formed. Streptococcus species are highly susceptible to erythromycin next to gentamycin while penicillin was not as such good as drug of choice. The study also disclosed that $E$. coli were highly susceptible to gentamycin and trimethoprim-sulfamethoxazole, while other antibiotics were found to be lower effective to $E$. coli. Moreover, most of the isolates were penicillin resistance in present study except $S$. aureus and Str. agalactiae those showed marked susceptibility to penicillin which that the result is comparable with (Birhanu et al., 2013).

\section{Conclusion and Recommendations}

This study showed high prevalence of bovine mastitis mainly due to the subclinical type and is a major health problem of dairy cows in the study farms. Bothcontagious and environmental pathogens such as S. aureus, Str. agalactiae, str. dysgalactiae, Str. uberis, other Staphylococcus spp, C. bovis, E. coli, P. aerogenosa, and $K$. pneumonie were among the isolated bacteria. Of this, staphylococcus and streptococcus species were the predominant isolates. Moreover, antimicrobial susceptibility testing on these major bacterial pathogens has revealed that Gentamycin and Trimethoprim-sulfamethoxazole were the most effective antibiotics, and could be the drug of choice where as penicillin and tetracycline were found to be poor in their efficacy to the major of the isolates.

Based on the conclusion set from the research work, the following recommendations are forwarded:

1. Proper husbandry practice is needed to control and prevent contagious and environmental mastitis causing bacteria.

2. Regular cleaning of the cows, using proper milking practices and milking of infected cows after apparently healthy animals should be practiced.

3. There should be periodic/regular mastitis check up.

4. Antimicrobial susceptibility test is important point to undertake measurable control options of mastitis in the dairy farms.

\section{References}

[1] Akers, R. M. (2002): Lactation and the Mammary Gland. Iowa State Press, Ames, Iowa, USA, 2002. Pp: 278.

[2] Almaw, G., Molla, W. and. Melaku A (2009): Prevalence of bovine subclinical mastitis in Gondar town and surrounding areas, Ethiopia. Livestock Ressearch Rural Development, 21 (7).

[3] Al-Majali, A. M., K. M. Al-Qudah, Y. H. Al-Tarazi and O. F. Al-Rawashdeh (2008): Risk factors associated with camel brucellosis in Jordan. Tropical Animal Health Production 40: 193-200.

[4] Ararsa, D., Tadele, T., and Aster, Y. (2014): Prevalence of clinical and sub-clinical mastitis on cross bred dairy cows at Holleta Agricultural Research Center, Central Ethiopia.
Journal of Veterinary Medicine and Animal Health 6 (1): 1317.

[5] Atyaib, N., Vodjgani M, Gharagozloo F, Bahonar A (2006): Prevalence of bacterial mastitis in cattle from the farms around Tehran. Iranian Journal of Veterinary Research 3 (16): 76-79.

[6] Bedada, B., and A. Hiko, (2011): Mastitis and antimicrobial susceptibility test at Asella, Dairy. Oromia Regional state, Ethiopia. Journal of Microbiology and Antimicrobial 3: 22823.

[7] Birhanu, A., Diriba, L., and Iyob, I. (2013): Study of bovine mastitis in asella government dairy farm of Oromia regional state, South Eastern Ethiopia. International Journal of Current Research and Academic Review 1 (2): 134-145.

[8] Biruk, D., and Shemeles, A. (2015): Isolation and identification of major bacterial pathogen from clinical mastitis cow raw milk in Addis Ababa, Ethiopia. Academic Journal of Animal Disease 4 (1): 44-51.

[9] Bishi, A. B. (1998): Cross sectional and longitudinal prospective study of bovine clinical subclinical mastitis in perurban and urban dairy production in Addis Ababa. MSc thesis, Addis Ababa university, Faculty of veterinary medicine, Debra Zeit, Ethiopia.

[10] Bitew M, Tafere A, Tolosa T (2010). Study on Bovine Mastitis in Dairy Farms of Bahir Dar and its Environs. Journal of Animal and Veterinary Advances, 9 (23): 29122917.

[11] Bradley, A. J. (2002). Bovine Mastitis: an Evolving disease. Veterinary Journal 163: 1-13.

[12] Capuco, A. V. et al. (1992): Increased susceptibility to intra mammary infection following removal of teat canal keratin. Journal of Dairy Science 75: 2126-2130.

[13] Central Statistical Agency (CSA) (2014): Livestock and Livestock Characteristics, Agricultural Sample Survey. Statistician Bulletin, 2 (537): 107.

[14] Dabash, H., Petros, A., and Fekadu, A. (2014): Prevalence and Identification of Bacterial Pathogens Causing Bovine Mastitis from Crossbred of Dairy Cows in North Showa Zone of Ethiopia. Global Veterinaria 13 (2): 189-195.

[15] Dego, O. K., and G. F. Tarek (2003): Bovine mastitis in selected areas of southern Ethiopia. Tropical Animal Health and Production 35 (3): 197-205.

[16] Demelash, B., Etana, D. and B. Fekadu, (2005): Prevalence and Risk Factors of Mastitis in Lactating. International Journal of Applied Research in Veterinary Medicine 21: 3.

[17] Enyew, G. A. (2004). A cross-sectional study of bovine mastitis in and around bahirdar and antibiotic resistance patterns of major pathogens. MSc thesis Addis Ababa University Debre Zeit, Ethiopia.

[18] Eriskine, R. J. (2001): Intramuscular administration of ceftiofursodiu versus intra mmamary infusion of penicillin/novobiocin for treatment of Streptococcus agalactiae mastitis in dairy cows. Journal of American Veterinary Medical Association 208: 258-260.

[19] FAO, (2009): Crop Diversification and Marketing Development Project, Interim Report. Addis Ababa, Ethiopia. 
[20] Fadlelmoula, A., Fahr, R., Anacker, G, Swalve, H (2007). The Management Practices Associated with Prevalence and Risk Factors of Mastitis in Large Scale Dairy Farms in ThuringiaGermany 1: Environmental Factors Associated with Prevalence of mastitis. Australian Journal of Basic and Applied science 1 (4): 619-624.

[21] Fekadu, K. (1995): Survey on Prevalence of Bovine Mastitis and the Predominant Causative Agent. In Proceeding of 9 Conference of Ethiopia Veterinary Association, Addis Ababa Ethiopia, Pp: 101-111.

[22] Girma, D. (2010): Study on prevalence of mastitis on cross Breed Dairy cows Around Holeta areas, West Shewa Zone of Ethiopia. Global Veterinaria 5 (69): 31 8-323.

[23] International Dairy Federation (1987): Bovine Mastitis: Definition and Guidelines for Diagnosis. Bulletin of the International Dairy Federation Pp. 211, 24.

[24] Hamann, J. (2005): Diagnosis of Mastitis and Indicators of Milk Quality. IN: Hogeveen, H. (Ed.) Proceedings of 4th IDF International Dairy Conference: Mastitis in Dairy Production Current Knowledge and Future Solutions. Pp. 82-90.

[25] Hogeveen, H, Huijps, K., and Lam, T. (2011): Economic aspects of mastitis: new developments. New Zealand Veterinary Journal, 59 (1): 16-23.

[26] Husien, N., Yehualashet, T., and Tilahun, G. (1999): Prevalence of Mastitis in Different Local and Exotic and Breed of Milking Cows. Ethiopian Journal of Agricultural Science, 16: 53-60.

[27] Junaidu, A. U., Salilu, M. D., Jambuwal, F. M., Magoji, A. A., and Jaafaru, S. (2011). Prevalence of mastitis in lactating cows in some selected commercial dairy farms in Sokoto metropolis. Advances in Applied Research, 2 (2): 290-294.

[28] Korhonen, H., and L. Kaartinen (1995): Changes in the composition of milk induced by mastits. In: The bovine udder and mastitis. Sandholm, M., T. Honkanen-Buzalski, L. Kaartinen and S. Pyörälä (eds.), University of Helsinki, Finland Pp. 76-82.

[29] Kerro, O., Tareke, F., (2003): Bovine mastitis in selected areas of Southern Ethiopia. Tropical Animal Health Production 35: 197-205.

[30] Lemma, M., Kassa, T., and Tegegne, A. (2001): Clinically manifested major problems cross breed dairy in urban and preurban production system in central highland of Ethiopia. Tropical Animal Health and Production 33: 85-89.

[31] Mekibib, B., Furgasa, M., Abunna, F., Megersa, B., and Regassa, A. (2010): Bovine Mastitis: Prevalence, Risk Factors and Major Pathogens in Dairy Farms of Holeta Town, Central Ethiopia. Veterinary world, 3 (9): 397-403.

[32] Moges, N., Asfaw, Y., and Belihu, K. (2011): A Cross Sectional Study on the Prevalence of Sub Clinical Mastitis and Associated Risk Factors in and around Gondar, Northern Ethiopia. International Journal of Animal health and Veterinary Advances 3 (6): 455-459.

[33] Mohamed, A., Simeon, E., and Yemesrach, A. (2004): Dairy development in Ethiopia. International Food Policy Research Institute, EPTD Discussion Paper No. 123. Washington, DC, U.S.A.

[34] Mulugeta, Y., and Wassie, M. (2013): Prevalence, risk factors and major bacteria causes of bovine mastitis in and around Wolaitasodo, Southern Ethiopia. African Jornal of Microbiological Research 7 (48): 5400-5405.

[35] National Committee for clinical laboratory standards (1997): Performance standard for antibial disc and dilution susceptibility test for bacteria isolated from animals and humans, humans, approved standard, NCCLS document M31a NCCLS, Villanova, PA.

[36] Nibret, M., Tekle. H., Tewodros. F., Mersha, C., and Achenafi, M. (2012): Bovine mastitis and associated risk factors in small holder lactating dairy farms in Hawassa, Southern Ethiopia. Global Veterinaria, 9 (4): 441-446.

[37] NMC, (1999): Current Concept in bovine mastitis National mastitis Council (NMC). 3rd. 1840 Wilsonblud, Arlinton, VA 22201.

[38] Paulrud, C. O. (2005): Basic concepts of the bovine teat canal. Veterinary Research Communication, 9: 215-245.

[39] Radostits, O. M., C. C. Gay, D. C. Blood and K. W. Hinchlif, (2007): Veterinary Medicine 9 Ed., Harcourt Ltd and London, Pp: 174-758.

[40] Quinn, P. J., Markey, B. K., Carter, M. E., Donelly, W. J., Leonard, F. C. (2002). Veterinary Microbiologyand Microbial Disease. Blackwell Science Ltd, a Blackwell publishing Company. Pp: 326- 475.

[41] Radostits, O., C. Gay, W. Hinchcliffand D. Constable (2007). Mastitis. In Veterinary Medicine: A Text book of disease of cattle, sheep, pigs, goats, and horses 10th edition, Ballier, Tindall, London. Pp: 674-762.

[42] Riollet, C. and Rainard, P. (2006): innate immunity of the bovine mammary gland. Veterinary Research 37: 369-400.

[43] Rehman, H. D., Sambyal, S., and Boxi, K. (1983): Incidence and etiology of subclinical mastitis in cows and buffaloes in Punja Agricultural university Ludhiana, India 20: 208-212. Sordillo, L. M., (2009): Current Concepts on Immunity and Mastitis. DCDS Advances in Dairy Technology 21: 111-119.

[44] Standard veterinary laboratory diagnostic manual (2005): ministry of agriculture and rural development animal health department 2: 158-160.

[45] Tsegai B (1997): Bovine mastitis in and around Bedele in zebu breed under village. DVM, Thesis submitted to the Faculty of Veterinary Medicine, Addis Ababa University, Ethiopia.

[46] Vandepitte, J. and Verhaegen, J. (2003): Basic laboratory procedures in clinical bacteriology $2^{\text {nd }}$ edition PP. 40-95.

[47] Workineh, S., M. Bayleyeng, M. Mekonnen, H., and Potgieter, L. (2002): Prevalence and Etiology of Mastitis in Cows from Two Major Ethiopia Dairies. Tropical Animal Health and Production 34: 19-25.

[48] Zerihun, T. (1996): A Study on Bovine Subclinical Mastitis at Stela Dairy Farm. DVM, Thesis submitted to the Faculty of veterinary Medicine, Addis Ababa University, Ethiopia.

[49] Zeryhun, T., Aya, T., and Bayecha, R. (2013): Study on Prevalence, Bacterial Pathogens and Associated Risk Factors of Bovine Mastitis In Small Holder Dairy Farms in and Around Addis Ababa, Ethiopia. Journal of Animal and Plant Science, 23 (1): 50-55. 